удк 657.421 .3

\title{
ОБЛІК НЕМАТЕРІАЛЬНИХ АКТИВІВ ЗГІДНО НАЦІОНАЛЬНИХ ТА МІЖНАРОДНИХ СТАНДАРТІВ: ШЛЯХИ ВДОСКОНАЛЕННЯ
}

\section{ACCOUNTING FOR INTANGIBLE ASSETS ACCORDING TO NATIONAL AND INTERNATIONAL STANDARDS: WAYS OF IMPROVEMENT}

\author{
Овсюк Ніна Василівна \\ доктор економічних наук, доцент, \\ Національний авіаційний університет \\ ORCID: https://orcid.org/0000-0002-8776-9503 \\ Лесько Марія Олександрівна \\ студент, \\ Національний авіаційний університет \\ ORCID: https://orcid.org/0000-0002-4489-5307 \\ Ovsyuk Nina, Lesko Maria \\ National Aviation University
}

\begin{abstract}
У науковій статті розглянуто важливі питання, які виникають під час здійснення українськими підприємствами операцій, пов'язаних з обліком нематеріальних активів. Проаналізовано останні дослідження та публікації науковців, присвячені організації обліку нематеріальних активів. Вивчено поняття «нематеріальні активи» відповідно до українських національних та міжнародних стандартів. Здійснено огляд відмінностей щодо визначення поняття «нематеріальні активи». Автори статті запропонували власне бачення сутності нематеріальних активів, яке ґрунтується на дослідженні нормативно-правових актів та працях науковців. У цій статті досліджено класифікаційні ознаки нематеріальних активів, а також особливості обліку операцій 3 нематеріальних активів, що здійснюються іноземними країнами.
\end{abstract}

Ключові слова: нематеріальні активи, облік нематеріальних активів, амортизація нематеріальних активів, міжнародні стандарти фрінансової звітності, бухгалтерський облік.

В научной статье рассмотрены основные вопросы, возникающие при учете нематериальных активов украинских предприятий. Проанализированы последние исследования и публикации ученых, посвященные учету нематериальных активов. Изучено понятие «нематериальные активы» в соответствии с украинскими национальными и международными стандартами бухгалтерского учета и фринансовой отчетности. Проведен обзор различий в определении понятия «нематериальные активы». Авторы статьи предложили собственное определение сущности нематериальных активов, основанное на исследовании нормативно-правовых актов и трудов ученых. В этой статье исследуется классификация нематериальных активов, а также особенности учета операций с нематериальными активами, что проводятся зарубежными странами.

Ключевые слова: нематериальные активы, учет нематериальных активов, амортизация нематериальных активов, международные стандарты фринансовой отчетности, бухгалтерский учет.

This scientific article reviews important issues that arise during the implementation of operations by Ukrainian enterprises related to the accounting of intangible assets. The article analyzes the latest research and publications of scientists devoted to the organization of non-material assets accounting. It was found that the inclusion of intangible assets into the resources of enterprises is the cause of increasing their market value, increasing investment privatization and indirect protection of rights and interests of economic entities. The notion of «intangible assets» according to Ukrainian national and international standards was studied. It was found that the lack of uniformity in the definition of «intangible assets» is the reason for incomplete understanding of the terminology by the business entity, which leads to ambiguity of interpretation by practitioners and impossibility to form a consensus, which will be stable and immutable, and fully disclose the definition of intangible assets. A review of the differences in the definition of «intangible assets» is made. The authors of the article offered their own understanding of the essence of 
intangible assets, which is based on the research of normative-legal acts and works of scientists. It is noted that the national regulations (standards) of accounting records are based on international standards of financial accounting. However, an effective view of all existing, but sometimes overlapping provisions of Ukrainian accounting of intangible assets requires regulation of normative and clarification of theoretical aspects. It should be emphasized that in comparison with foreign companies the share of intangible assets in the balance sheets of domestic companies is insignificant. This is due to the lack of formation of the Ukrainian market of intangible assets, which prevents the active development of our economy. It was found that the sphere of non-material assets accounting is insufficiently specified. There are a lot of inaccuracies that occur both in the legislation and arise already in the process of practical activity of the company. That is why a lot of efforts and costs should be spent to create such conditions, which could improve the current situation and create conditions for rational and effective accounting of intangible assets at domestic enterprises. This article examines the classification and classification features of intangible assets, as well as peculiarities of the accounting of operations with intangible assets, which are carried out by foreign countries.

Keywords: intangible assets, accounting for intangible assets, amortization of intangible assets, international financial reporting standards, accounting.

Постановка проблеми. Сьогодні економічний розвиток України знаходиться на такому рівні, що більшість існуючих підприємств та організацій активно беруть участь у процесі залучення та розвитку нематеріальних активів. Включення нематеріальних активів до ресурсів підприємств є причиною підвищення їх ринкової вартості, зростання інвестиційної привабливості та безпосереднього захисту прав та інтересів суб'єктів господарювання.

Слід зазначити, що національні положення (стандарти) бухгалтерського обліку ґрунтуються на міжнародних стандартах фрінансової звітності. Проте, ефективний нагляд за всіма існуючими, але водночас суперечливими положеннями українського обліку нематеріальних активів, потребує регулювання нормативних та уточнення теоретичних аспектів. Слід зазначити, що порівняно з іноземними компаніями частка нематеріальних активів у балансах вітчизняних підприємств $€$ незначною. Це пов'язано 3 недостатнім фрормуванням українського ринку нематеріальних активів, що перешкоджає активному розвитку нашої економіки.

Аналіз останніх досліджень і публікацій. Дослідженням проблем обліку нематеріальних активів присвячені праці таких вчених: Банасько Т.М., Бігдана І.А., Бородіна Ю.І., Бутинця Ф.Ф., Валуєва Б.І., Гладунова В.Д., Добровського В.О., Криштопа І.І., Кужельного М.В., Лінник В.Г., Польової Т.В., Сопка В.В., Шевчука В.О., Шульги С.В. та інших. Але, незважаючи на значну кількість публікацій, проблеми обліку нематеріальних активів залишаються актуальними та потребують вирішення з урахуванням сучасного стану розвитку.

Виділення невирішених раніше частин загальної проблеми. Бухгалтерський облік нематеріальних активів завжди актуальний у господарській діяльності підприємств. В основному це стосується визначення та класифрі- кації нематеріальних активів. Питання визначення окремих понять, класифрікаційних ознак та належного обліку відповідних об'єктів хвилюють провідних вчених та викликають суперечки між ними через різноманітність думок. Розвиток науки сприяє виникненню дискусій щодо правильної організації обліку нематеріальних активів, що потребує подальшого дослідження.

Формулювання цілей статті (постановка завдання). Основною метою даної статті $€$ дослідження проблем обліку нематеріальних активів в Україні та пошук шляхів його вдосконалення з урахуванням використання МСФЗ.

Виклад основного матеріалу дослідження. 3 точки зору бухгалтерського обліку національні та міжнародні стандарти по-різному трактують поняття «нематеріальний актив».

Відповідно до Міжнародного стандарту бухгалтерського обліку 38, нематеріальні активи визначаються як немонетарні активи, які не мають фрізичної субстанції та можуть бути ідентифріковані [1].

Національний стандарт бухгалтерського обліку 8 «Нематеріальні активи» визначає нематеріальні активи як немонетарні активи, які не мають матеріальної фрорми та які можна ідентифрікувати [2].

Податкове законодавство України окреслює нематеріальні активи як право власності на результати інтелектуальної діяльності, включаючи права промислової власності та інші подібні права, які визнаються об'єктом власності, право користування майном та права власності, якими користуються платники податків в установленому порядку. У тому числі право користування природними ресурсами, права власності та майнові права, набуті в установленому законодавством порядку [3].

Відсутність єдності у визначенні поняття «нематеріальні активи» $€$ причиною недостовірного розуміння суб'єком господарювання термінології, що призводить до неоднознач- 
ності тлумачення практиками та неможливості формування консенсусу, який буде стабільним і незмінним, і повною мірою розкрити визначення нематеріальних активів.

Для суб'єктів господарювання, які здійснюють зовнішньоекономічну діяльність, тобто міжнародних компаній або суб'єктів господарювання $з$ іноземними інвестиціями, ця проблема $є$ особливо серйозною, оскільки неправильне розуміння поняття «нематеріальний актив» та його використання у підприємницькій діяльності може спотворювати дані та безпосередньо впливати на фрінансову звітність, а також виступати як результат прийняття неефективних управлінських рішень.

Податкове законодавство України передбачає, що нематеріальні активи є лише майновими правами, хоча насправді їх склад значно ширший.

3 метою унісрікації трактування поняття «нематеріальні активи» та створення необхідних умов для найбільш точного та конкретного відображення в системі бухгалтерського обліку і звітності необхідно вказати такі характеристики об'єкта, наприклад:

1) утримання на підприємстві для використання, а не в якості інвестицій;

2) визначення терміну використання понад один рік;

3) оцінка залежно від здатності генерувати дохід для власників;

4) поступова втрата вартості і списання ії на витрати шляхом нарахування амортизації;
5) наявність великого ступеня невизначеності $з$ приводу майбутніх вигод, що можуть походити з фракту використання нематеріального активу;

6) можливість мати цінність для декількох підприємств [5, с. 32].

Отже, проаналізувавши дані, ми можемо узагальнити формулювання та належним чином визначити поняття «нематеріальний актив». Таким чином, можна припустити, що «нематеріальний актив» - це немонетарний актив, який не має матеріальної форми, може бути ідентиорікований і утримується підприємством більше одного року або операційного циклу, використовується у фрінансово-господарській діяльності підприємства з ціллю одержання вигід від його використання у майбутньому.

Щоб краще зрозуміти напрямок розкриття поняття «нематеріальний актив», краще глибше зрозуміти їх класифрікацію. 3 цією метою в табл. 1 аналізуються класифрікаційні ознаки та види нематеріальних активів.

Нематеріальні активи мають специсрічні характеристики з облікової точки зору щодо нарахування та списання на витрати підприємства амортизації, визначення терміну служби тощо.

Розглядаючи основні види нематеріальних активів та аналізуючи їх, дуже важливим розуміти, до якої класифрікаційної групи належить той чи інший нематеріальний актив. Зрештою, підприємства мають велику кількість нематеріальних активів, які потребують достовірної

Таблиця 1

Класифікація нематеріальних активів

\begin{tabular}{|c|c|}
\hline Ознака & $\begin{array}{c}\text { Види } \\
\end{array}$ \\
\hline $\begin{array}{l}\text { Згідно з планом рахунків } \\
\text { бухгалтерського обліку }\end{array}$ & $\begin{array}{l}\text { - права користування природними ресурсами; } \\
\text { - права користування майном; } \\
\text { - права на комерційні позначення; } \\
\text { - права на об'єкти промислової власності; } \\
\text { - авторське право та суміжні з ним права; } \\
\text { - інші нематеріальні активи }\end{array}$ \\
\hline За строком корисного використання & $\begin{array}{l}\text { - фрункціонуючі; } \\
\text { - не фрункціонуючі }\end{array}$ \\
\hline За ступенем відчуження & $\begin{array}{l}\text { - відчужувані; } \\
\text { - невідчужувані }\end{array}$ \\
\hline За ступенем правової захищеності & $\begin{array}{l}\text { - захищаються охоронними документами; } \\
\text { - не захищені }\end{array}$ \\
\hline За оборотністю & $\begin{array}{l}\text { - поточні; } \\
\text { - довгострокові }\end{array}$ \\
\hline $\begin{array}{l}\text { За ступенем впливу на фрінансові } \\
\text { результати }\end{array}$ & $\begin{array}{l}\text { - здатні безпосередньо приносити дохід; } \\
\text { - опосередковано впливають на фрінансові результати }\end{array}$ \\
\hline За способом створення & $\begin{array}{l}\text { - власні; } \\
\text { - пайові; } \\
\text { - придбані зі сторони }\end{array}$ \\
\hline
\end{tabular}

Джерело: систематизовано авторами за матеріалами [4] 
оцінки та належної класифрікації. Визначення правильної класифрікаційної групи залежить від ролі та ступеня участі певного нематеріального активу у фрінансово-господарській діяльності підприємства, де він відіграє важливу роль щодо поступового перенесення своєї вартості протягом терміну корисного застосування на витрати суб'єкта господарювання.

Звертаємо увагу, що поняття «нематеріальні активи» вважається одним із найскладніших понять в бухгалтерському обліку і вимагає великої уваги та ретельного вивчення. Це пов'язано з невизначеністю оцінки та строку корисного використання окремих видів нематеріальних активів. Поясненням цієї проблеми слугує відсутність єдиного переліку витрат, що фооммють первісну вартість нематеріальних активів. Залежно від групи, до якої належать витрати, їх можна віднести до первісної вартості формування нематеріальних активів (тобто витрат, пов'язаних із придбанням товарів, транспортними послугами чи монтажем) або до витрат на управління. При цьому виникає питання про складність оцінки нематеріальних активів, що пов'язано з відсутністю єдиної методики оцінки майбутніх економічних вигод від використання таких об'єктів. При визнанні нематеріальних активів передбачається, що вони будуть використовуватися протягом тривалого часу.

Однак, у перспективі довгострокової діяльності суб'єкта господарювання виникає проблема прогнозування ймовірності підтвердження доходу від використання нематеріальних активів. Тут важливу роль грає стратегічний план, який передбачає термін корисного використання об'єкта необоротних активів i, таким чином, прогнозує термін його корисного використання на підприємстві. Процес стратегічного планування дуже важливий, оскільки допомагає точніше визначити вплив нематеріальних активів, які беруть участь у бізнес-процесах, на результати господарської діяльності.

Невирішеним питанням також залишається питання відображення в обліку нематеріальних активів, створених підприємством під час виконання замовлень для фрізичних осіб та інших організацій.

Відповідно до НП(С)БО 8 первісна вартість нематеріального активу, який створений підприємством, визнається в бухгалтерському обліку на основі собівартості всіх прямих витрат, що були понесені суб'єктом господарювання [2]. Проте, оцінка аналогічного необоротного активу, який надходить на під- приємство за справедливою вартістю, може істотно відрізнятися від собівартості цих статей, i ця різниця може бути як нижчою, так i вищою. Тому, необхідно підтвердити вартість нематеріального активу, створеного підприємством, незалежно від фрактичної собівартості, або справедливої вартості за допомогою відповідного методу оцінки. Ось чому підприємство самостійно, керуючись певними принципами діяльності або існуючими правилами бухгалтерського обліку, визначає порядок відображення новостворених нематеріальних активів і повинно визначити бажаний варіант оцінки для конкретної групи чи окремого об'єкта відповідно до облікової політики або окремих об'єктивних даних щодо оцінки нематеріальних активів.

Амортизація нематеріальних активів представляє собою поступове списання вартості нематеріальних активів під час їх використання на витрати. Вона спрямована на компенсацію витрат, понесених підприємством в процесі придбання нематеріальних активів, і забезпечення джерела фрормування коштів для відновлення цих активів.

Амортизація нараховується щомісяця, починаючи 3 місяця, наступного за моментом, коли об'єкт стає доступним для використання, і закінчуючи місяцем, наступним за місяцем вибуття. Амортизація не залежить від фрінансових результатів підприємства. Основна проблема, яка виникає при нарахуванні амортизації нематеріальних активів, полягає в тому, що вони не можуть бути віднесені до окремої групи, а також у відсутності конкретного законодавчого регламенту, що міститиме положення щодо здійснення відповідних амортизаційних відрахувань.

Отже, НП(С)БО 7 включає методи нарахування амортизації, але вони відносяться до необоротних активів загалом і не охоплюють конкретні групи об'єктів [6]. Прирівнювати ці об'єкти неможливо, тому що розрахунок амортизації повинен проводитися за абсолютно різних умов, характерних для певної групи об'єктів. Ось чому необхідність виділення існуючих методів амортизації або створення нових методів має стати основою для вирішення цієї проблеми. Адже з часом важливість та кількість нематеріальних активів на підприємстві лише зростатиме.

Сьогодні сучасні українські підприємства самостійно обирають метод амортизації нематеріальних активів відповідно до умов отримання економічних вигод у майбутньому. Якщо це неможливо визначити, амортизація 
нематеріальних активів розраховується за допомогою прямолінійного методу. У разі можливого довгострокового планування діяльності, підприємство має можливість вибрати будь-які інші існуючі методи, але ці зміни мають бути зазначені в наказі про облікову політику підприємства.

Висновки. Поняття «нематеріальні активи» потребує подальших глибоких та всебічних досліджень. Незважаючи на поступове впровадження міжнародного досвіду до вітчизняного законодавства, значні відмінності щодо обліку нематеріальних активів в Україні та світі спостерігаються і зараз.

Першочерговим завданням процесу регулювання обліку нематеріальних активів $€$ адаптація системи бухгалтерського обліку до міжнародних стандартів та внесення змін до існуючої законодавчої бази $з$ метою забезпечення їх гармонізації. В умовах постійних глобалізаційних процесів, які зачіпають низку країн, певним чином об'єднуючи їх, невідкладним для багатьох українських підприємств, що прагнуть досягнути успіху, $є$ завдання залучати іноземних інвесторів і надавати їм зрозумілу інорормацію та звітність у відповідності до МСФЗ.

Диспропорції, що спостерігаються на сьогодні, $€$ причиною низки невідповідностей у даній сорері. Вирішення таких проблем потрібно починати саме 3 транссрормації законодавства, що стане підгрунтям для розв'язання інших, більш масштабних питань.

Водночас виникає необхідність постійного підвищення кваліфрікації вітчизняних бухгалтерів щодо обліку нематеріальних активів. Але в Україні такі питання хвилюють лише суб'єктів підприємницької діяльності, які особисто зацікавлені у багатопрофрільному працівнику, тоді як інші вважають за доцільне не витрачати власні кошти в цьому напрямі. У створенні умов, які б сприяли ефрективній організації, раціональному веденню та управлінню об'єктами нематеріальних активів, треба зацікавити не тільки власників підприємств, що забезпечують виконання цих вимог, а й державу, яка має можливість глибоко і детально підійти до даного питання. Необхідність розробки методичного забезпечення щодо контролю над обліком нематеріальних активів підприємства дасть можливість ефективно їх використовувати у процесі фрінансово-господарської діяльності шляхом чіткого декларування усіх ситуацій, що можуть виникнути.

Основними питаннями, які потребують негайного та ефективного втручання, слід зазначити: різноманітність трактувань поняття «нематеріальні активи» у вітчизняному законодавстві та наявність відмінностей у відношенні до міжнародних стандартів, що унеможливлює виділення єдиного визначення та призводить до непорозумінь у сорері зовнішньоекономічної діяльності; неможливість виділення єдиного підходу в нормативно-правових актах щодо методики обліку нематеріальних активів, що призводить до неодноманітного відображення цих видів активів у звітності підприємств; відсутність сталої та незмінної класифрікаційної системи, що могла б значно полегшити облік об'єктів нематеріальних активів; розбіжності у методах нарахування амортизації нематеріальних активів, що призводить як до заниження, так і до завищення їх первісної вартості; проблематика у визначенні строків корисного використання активів.

Таким чином, сорера обліку нематеріальних активів недостатньо конкретизована. $€$ безліч неточностей, які зустрічаються як у законодавстві, так і виникають вже у процесі практичної діяльності підприємства. Тому наразі потрібно спрямувати безліч зусиль та коштів для створення таких умов, які б змогли покращити існуючу ситуацію та створили б підгрунтя для раціонального та ефективного обліку нематеріальних активів на вітчизняних підприємствах.

\section{СПИСОК ВИКОРИСТАНИХ ДЖЕРЕЛ:}

1. Міжнародний стандарт бухгалтерського обліку 38 «Нематеріальні активи»: Міжнародний документ від 29.03.2021. URL: https://www.mof.gov.ua/storage/files/IAS\%2038_ukr\%202020.pdf

2. Національне Положення (стандарт) бухгалтерського обліку 8 «Нематеріальні активи» : Наказ Міністерства фрінансів України № 242 від 18.10.1999. URL: http://zakon0.rada.gov.ua/laws/show/ z0750-99

3. Податковий кодекс України : Кодекс України № 2755-VI від 02.12.2010. URL: http://zakon3.rada.gov.ua/ laws/show/2755-17

4. Сизоненко О.В. Класифікація нематеріальних активів з метою ефективного забезпечення виконання завдань бухгалтерського, управлінського обліку та аналізу. URL: http://www.nbuv.gov.ua/old_jrn/Soc_Gum/ Menedzhment/2010_13/suzonenk.htm 
5. Банасько Т.М. Проблеми та перспективи дослідження нематеріальних активів в Україні. Економіст. 2014. № 2. С. 30-33.

6. Національне Положення (стандарт) бухгалтерського обліку 7 «Основні засоби» : Наказ Міністерства фрінансів України № 92 від 27.04.2000. URL: http://zakon5.rada.gov.ua/laws/show/z0288

\section{REFERENCES:}

1. Mizhnarodnyi standart bukhhalterskoho obliku 38 «Nematerialni aktyvy»: Mizhnarodnyi dokument vid 29.03.2021 [International Accounting Standard 38 «Intangible Assets»: International document dated 01.01.2012]. Retrieved from: http://zakon3.rada.gov.ua/laws/show/929_050

2. Natsionalne Polozhennia (standart) bukhhalterskoho obliku 8 «Nematerialni aktyvy»: Nakaz Ministerstva finansiv Ukrainy № 242 vid 18.10.1999 [Regulation (standard) of accounting 8 «Intangible assets»: Order of the Ministry of Finance of Ukraine 2242 from 18.10.1999]. Retrieved from: http://zakon0.rada.gov.ua/laws/show/z0750-99

3. Podatkovyi kodeks Ukrainy: Kodeks Ukrainy № 2755-VI vid 02.12.2010 [Tax Code of Ukraine: Code of Ukraine № 2755-VI of 02.12.2010]. Retrieved from: http://zakon3.rada.gov.ua/laws/show/2755-17

4. Sizonenko O.V. Podatkovyi kodeks Ukrainy: Kodeks Ukrainy № 2755-VI vid 02.12.2010 [Classification of intangible assets in order to effectively ensure the implementation of tasks of accounting, management accounting and analysis]. Retrieved from: http://www.nbuv.gov.ua/old_jrn/Soc_Gum/Me-nedzhment/2010_13/suzonenk.htm

5. Banasko T.M. (2014) Problemy ta perspektyvy doslidzhennia nematerialnykh aktyviv v Ukraini [Problems and prospects of research of intangible assets in Ukraine]. Economist, 2, 30-33.

6. Natsionalne Polozhennia (standart) bukhhalterskoho obliku 7 «Osnovni zasoby»: Nakaz Ministerstva finansiv Ukrainy № 92 vid 27.04.2000 [Regulation (standard) of accounting 7 «Fixed assets»: Order of the Ministry of Finance of Ukraine № 92 of 27.04.2000]. Retrieved from: http://zakon5.rada.gov.ua/laws/show/z0288 